\title{
THE CONDITIONED IMPACT OF RECESSION NEWS: A TIME-SERIES ANALYSIS OF ECONOMIC COMMUNICATION IN THE UNITED STATES, I $987-$ I 996
}

\author{
H. Denis Wu, Robert L. Stevenson, Hsiao-Chi Chen \\ and Z. Nuray Güner
}

\begin{abstract}
This study examined the complex relationships among recession news, the state of the economy, and people's perceptions toward the economy from January 1987 through March I 996 using trivariate vector autoregression (VAR) analysis. Most of the time-series variables were found to have structural changes during this time frame. With the help of the Chow test, the researchers were able to determine January i99 I as the cut-off point to divide the entire period into two: downturn period and recovery period. The relationships among these three time-series were found to be dramatically different across the two distinct periods. The paper concludes that: (I) the situational factor (different states of economy) played a crucial role in determining how the public evaluates the economy; (2) the extent to which recession news' impact on people's assessment of the economy depended on different economic circumstances; (3) news coverage responded differently across these two distinct periods but, in the long run, followed the economic reality; and (4) the public's sentiments toward the economy can predict economic performance.
\end{abstract}

If mass media have the power to influence audiences-a key but not easily provable assumption of the field - do they also have the power to influence the events that are the basis of the news? This Heisenberg-like principle is not often addressed in research but does represent a facet of media influence that deserves attention. And the practical question of media as forces shaping public events as well as the public response occasionally makes the political agenda. A case in point was whether negative reporting of economic conditions in the USA in the early I990s, in fact, helped to precipitate the recession that propelled

This article was first submitted to IJPOR October I6, 2000. The latest version was received March 27, 2001 . 
the Clinton Administration into power with the famous campaign staff reminder, 'It's the economy, stupid'.

In this article, we consider the influence of reporting on events themselves as well as on the audience, using a decade of aggregate data from the USA that includes a simple computer-assisted content analysis, a repeated measure of public perceptions of economic conditions, and indicators of the state of the economy itself. A time-series analysis technique is used to sort out time order and other aspects of the dynamics of a complex public issue that involves reality, reporting, and public response.

Assessing mass media influence is a tough job. Among the difficulties are (I) sorting out time order; (2) linking media content to changes in individuals' attitudes or behavior; and (3) extrapolating from typical short-term studies of individuals to long-term influence on larger social systems. A modest but important trend in the field is to shift from traditional experiments, surveys, and content analyses to data sets that are compiled from existing information archives over a relatively long period of time. The advantages are that one can surmount the difficulties noted here in ways that are not possible with traditional methods. The disadvantages include the restriction to problems that can be addressed from existing sources of information unless one is prepared to collect data for weeks and months, if not years, before beginning analysis. Fortunately, the growth of social indicator data and expansion of electronic news archives open a number of possible case studies of media influence.

As early as I990, the Washington Post media critic asked, 'Is the economy suffering from media malady?' (Kurtz I990). The argument from some government officials was that the media, by attention to (if not obsession with) the possibilities of an economic recession in the USA, had, in fact, helped to bring about a downturn that was later widely considered to be a key factor in George Bush's loss to Bill Clinton. As the threat of recession returned a decade later, the Economist, in its usual style of creative reporting, plotted the frequency of the 'r-word' in the New York Times and Washington Post alongside the state of the economy and concluded that the two followed one another but did not speculate on any causal effect ('Rrrrrrrrecession?' 200I). The Post's Kurtz was prepared to acknowledge media influence, but others (Gergen I992, Samuelson 1990) argued that both media coverage and public opinion were driven by events. The economy really was in retreat, a condition that drove both reporting and public response.

\section{THE ECONOMY AS A CASE STUDY}

Covering a complex issue is hard, especially if the reporting itself becomes part of the story. Economic situations are good examples of stories that challenge journalists' expertise and judgment. On the one hand, it is imperative to keep 
the audience abreast of the current status of the economy; on the other, emphasis on future conditions can become a self-fulfilling prophecy. In the early i 990 os, the media were blamed for harming an already weakened economy-the term 'media malady' was invoked often to describe the scenario. However, others defended their stories as simply reflecting hard facts and not intentionally influencing the economy. Therefore, the relationship between news coverage and the state of the economy, a relationship that has yielded debates about their mutual influences, is worth thorough investigation.

In addition to the usual relationship between media content and public effect, this study also examines the relationship between the economy and public perception. The state of the economy itself can be affected by public confidence (Katona 1964), because policy is influenced, in part, by public opinion. Linden (I982), however, argued that the public is more sensitive to day-to-day economic experiences than to the news: people's perception of the economy is shaped by what they observe in their everyday lives, not what they read in the papers. Thus, at issue here is whether the public's perception drives the economy or vice versa, and which direction of the influence is more significant.

The third relationship in this project is no less important. Media effect is the most important area in mass communication research. Studies have shown that news can generate a wide range of impacts on audiences. On the other hand, the traditional function of news is to mirror public opinion and to monitor social change-surveillance is one of the media's primary functions (Wright I960). For example, Gonzenbach (1996) found that news media reflected public opinion on drug issues and that the reverse direction of impact was not as significant.

News coverage, public opinion, and economic situation should be examined simultaneously because they can all reinforce and influence each other over time; in addition, these variables are not likely to be endogenous under any circumstance. Particularly because the economy is an obtrusive issue-in addition to media the public can obtain information about the economy from other sources - reality cues must be taken into account when media effect is assessed.

Conventional media effect studies usually assess public opinion change across two points in time, ignoring the potential long-term impact and the fluctuation between the times examined. Brosius and Kepplinger (I990), in their review of agenda-setting studies, pointed out that longitudinal analyses are quite rare and may complement traditional studies rather than challenge them. Not until the I 990 o did researchers examine the changes in public opinion on certain issues over longer periods (e.g., Gonzenbach I996, McCombs and Zhu 1995) or use time-series analysis methods to trace the media's impact (e.g., Brosius and Kepplinger 1990, Brosius and Weimann 1996, Iyengar and Simon 1993, Willnat and Zhu I996). These recent studies indicate that public opinion really does 
shift at different times because of changing political climates, governmental policies, or media coverage.

Another common characteristic of public opinion research is that most studies have focused on psycho-cognitive or demographic traits of individuals and how these factors lead to individual-level change. In other words, the dependent variables often represent micro-level data such as attitude, knowledge, or behavior instead of the macro-level counterparts. As a result, the route for tapping into the long-term shift of public opinion on any issue is less often taken. This study is concerned with the general public's assessment of the economy, so aggregation of an individual's opinions is more appropriate conceptually as well as necessary methodologically.

Only a handful of studies have specifically tackled these multifaceted relationships among news coverage of recession, the state of the economy, and the public's perception. Stevenson, Gonzenbach, and David's (1994) study, a pioneering work on this subject, found some cyclical effects between news coverage and people's perception toward the economy. More specifically, they discovered that, when economic reality is controlled, public opinion strongly influenced media coverage, but the media in turn followed the upsurge of public concern and influenced back at a later date. Overall, however, they found that the public's evaluations of the economy had a stronger effect on media coverage than vice versa.

Using the advanced vector autoregression (VAR) test, Blood and Phillips (I995) also examined the same three variables but produced a different result from Stevenson et al.'s. Among the relationships they examined, after controlling for the economic Leading Indicators, only the number of news articles that contained recession headlines was found to influence consumer sentiment (at lags of two months and four months). Other than this notable finding, none of other relationships examined turned out to be statistically significant. In the same year, Goidel and Langley (1995) conducted a similar study that explored the impact of economic news on the public's evaluation and its repercussion on presidential approval. With a measure of the story's tone, they found that negative economic news was more likely to reflect the economic situation in the $198 \mathrm{I}-92$ period. In addition, when various economic indicators were held constant, negative stories were found to influence public appraisal of the economy. Bowing to the limitation of the method used, however, they did not distinguish the magnitudes of influence generated by news and reality, respectively.

Haller and Norpoth (1997) took a slightly different approach to gauge economic news impact on people's appraisal of the economy. Using data from I979 to I990, they discovered that news played only a modest role in providing people with economic information; news exposure did not lead to a significant improvement of capability in assessing the economic situation. Measures of 
economic conditions such as unemployment and inflation contributed more to economic opinion. The problem of reciprocal influence between news and public evaluation, however, was not resolved by this study. In addition, the operationalization of news as news recall might introduce a problem of validity. Their study period, which does not include the last US recession, also points to a pressing need for the current study.

A number of studies conducted by political scientists also tackled the relationships among the variables that relate to this study. Behr and Iyengar (1985) investigated the determinants of news coverage and public concern, respectively, using energy, unemployment, and inflation as the test issues. Their results indicated that overall news coverage was not influenced by a shift of public concern. Rather, media coverage was more likely to be led by reality and relevant events. Public concern, on the other hand, was determined more by reality indicators than by news coverage, indicating a limited effect of the media.

MacKuen et al. (I992) examined the impact of people's sentiment toward the economy upon the ratings of presidential approval. With the discovery of the impact of business expectation on political evaluation, they set out to examine the sources of influence on business expectation. After controlling for economic reality, news recall was found to be a significant predictor, and that influence was powerful enough to remove the economic indicator from the prediction model. Several factors that might considerably influence the results, however, are worth pointing out. Data used in this study, unlike other studies, were quarterly; secondly, traditional regression methods rather than time-series analysis were used.

Additional support of the thesis of the media's influence in shaping economic evaluations can be found in Mutz's (I992) study. In line with Haller and Norpoth (I997), she discovered that personal experiences such as unemployment, along with local newspaper coverage, contributed to an individual's perception of the unemployment issue; with economic problems at the national level, people relied on media for information and making political judgment. The results indicated an interesting pattern of information sources that people use to help form their opinion. Nevertheless, the author's acknowledged limitations of sample location, time frame, and cross-sectional method are a disappointment.

It is apparent that past studies have yielded strikingly inconsistent and, in some cases, ambiguous results. Most of the studies indicated that media affect people's perception about the economy, but it is uncertain which of the two variables, news coverage or the economic reality, is more potent. For example, MacKuen et al. (I992) and Behr and Iyengar (I985) drew opposite conclusions on the impact of news and reality on the public. The contradiction between these empirical studies is probably derived from the adoption of distinct methods, different sample periods, varied operationalizations of news coverage and people's perception toward the economy, and different observation units 
and lags. Our research is designed to resolve the flaws of past studies by investigating further this tripartite relationship during the entire recession period.

\section{THE DATA}

In order to get a more complete scenario, a time frame was selected that would cover the periods well before and after the recession period (around 1989-90). ${ }^{1}$ Data representing these three variables used in this analysis were gathered from various sources. For a measure of newspaper coverage of economic recession, we retrieved the monthly frequency of New York Times news stories that contained recession' in the headline or lead from NEXIS, an on-line information service. ${ }^{2}$ The Nem York Times was chosen to represent the news coverage of recession because it is the leading elite national newspaper (Winter and Eyal I98I) as well as an important source of influence for other media (Brown 1971, Breed 1955, Crouse 1972, Reese and Danielian 1989). The simple frequency of news stories covering recession was used, in part, to make this study comparable with other related studies and, in part, to avoid the drudgery of a traditional content analysis of decade-long news coverage. In a test of the method, the frequency of news stories was found to be significantly correlated with the number of column inches devoted to a variety of topics (Stone and McCombs I98I).

The data used to represent the variable of people's perception-including present situation, expectation, and confidence-were gathered from the Consumer Research Center of the Conference Board. These three indices were calculated from five questions asked in nation-wide, monthly surveys of about 3,000 adults, I 8 years of age and older. These questions are:

I. How would you rate the present general business conditions in your area-good, normal, or bad?

2. Six months from now, do you think they will be-better, same, or worse?

3. What would you say about available jobs in your area right now-plenty, not so many, or hard to get?

4. Six months from now, do you think there will be-more jobs, same, or fewer jobs?

5. How would you guess your total family income to be six months from now-higher, same, or lower?

The positive, negative, and neutral response proportions to each survey question

\footnotetext{
${ }^{1}$ This procedure of including a longer sample also responds to the finding of Watt et al. (I993) that coverage of obtrusive issues generates longer effects than coverage of non-obtrusive issues.

${ }^{2}$ We also retrieved the news stories that include 'recession' in the news text. While the correlation between the total derived from the above method and the total of the stories that contain 'recession' in the headlines or leads reaches as high as $.95^{8}$; in addition, the shapes of their graphic lines across the time frame look almost identical.
} 
were seasonally adjusted by the Conference Board. For each of the five questions, the positive figure was divided by the sum of the positive and negative to yield a proportion, which the Conference Board calls the 'relative value'. The average relative value for the calendar year 1985 was used as a benchmark or base. The relative values for the current month was divided by the base and multiplied by Ioo to yield the index value for each question. The present situation index is the average of indices for questions I and 3 ; the expectation index is the average of indices for questions 2,4 , and 5 .

Finally, the 'reality' variable - the overall state of the economy in the USA - was represented by the Economic Index, which was calculated and maintained by the US Department of Commerce until it was taken over by the Conference Board. The index is based on I components and is estimated using the calendar year 1987 as the base. The components include: (I) average working week of production workers in manufacturing; (2) average weekly claims for state unemployment insurance; (3) new orders for consumer goods and materials, adjusted for inflation; (4) vendor performance (e.g. companies receiving slower deliveries from suppliers); (5) contracts and orders for plant and equipment, adjusted for inflation; (6) new building permits issued; (7) change in manufactures' unfilled orders for durable goods; (8) change in sensitive materials prices; (9) index of stock prices; (Iо) money supply, adjusted for inflation; and (II) index of consumer expectations. The index covers a wide range of economic factors in society, but it should be noted that it includes a minor component of consumer expectation, which might cause a concern of multicollinearity with the public's expectation measure.

All of the data in our sample are from January 1987 through March 1996. Because all of the data were measured and recorded monthly, the total of cases observed is III, which meets the requirement for implementing time-series analysis. Research does not agree on the issue of time lag between the appearance of news coverage and subsequent prediction of public opinion; instead, different optimal time spans for various issues have been noted (e.g. Brosius and Kepplinger 1990). Because economic problems are obtrusive domestic issues, according to Watt, Mazza and Snyder (I993), their optimal effect span is supposed to be longer. This fact justifies the use of monthly data. It is also worth noting that the indices of people's perception toward the economy are measured in the middle of each month, while other variables in the study like news coverage are gauged on a whole month's output, the examination of synchronous relationships (at lag o) between these variables is limited.

\section{RESULTS}

All of the data were analyzed with a commercially available program, Regression Analysis for Time Series (RATS). The unit root tests (both Dickey-Fuller and 


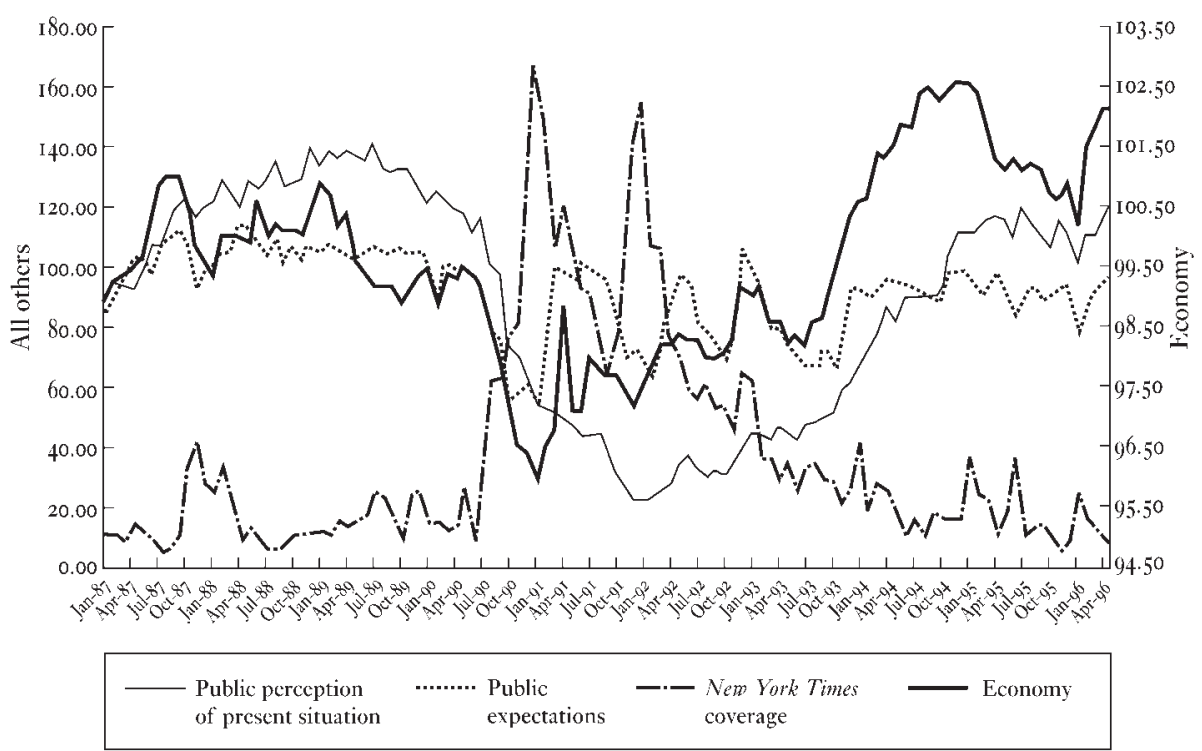

Figure I Development of the economy, media coverage, and public opinion

Phillips-Perron) were first conducted to see whether each series of the data has a mean and/or variance that are time-dependent. Based on the results of both tests, all the variables included in this study were found to be nonstationary series. These variables, therefore, have met the fundamental requirement of the Johansen test, which aims to investigate whether a group of nonstationary time-series variables are cointegrated. Meanwhile, a graphic chart of each variable in the time frame was made to show the general trend. The state of the economy appears to hover around Ioo before July I990 and then plunges sharply to the lowest point in January I99I. After that date, the slope starts to climb and reaches a peak in December 1994 (see Figure I). Precisely mirroring this trend, the number of Nem York Times stories about recession rockets to a peak twice in January I99 I and January I992, respectively, and then decreases sharply right after January 1992. The indices of people's perceptions toward the economy vary to some extent, but reflect a similar trend. The index of people's evaluation on present situation resembles a roller coaster ride; the public's expectation also has rapid ups and downs during the recession period. Interestingly, the evaluation of the present situation and expectation reach the lowest point at different times-expectation reaches the nadir in January I99I, while the present situation index falls to the bottom in December of the same year, indicating a reasonable lag between the present and the future.

Figure I also indicates the possibility of a structural break with these indices, since a turmoil period between May I990 and January I 994 can easily be seen 
and the trends prior to and after the period are significantly distinct. The Chow test (Johnston I99I, pp. 507-9) was conducted to help determine this structural break. Based on Figure I, all time-series seem to change their direction of slopes around January I99I. To inspect the existence of structural change and to select the best point to capture the largest magnitude of structural change in the three variables, a monthly examination from December I989 through January I 993 was implemented. The Chow test result indicates that indeed there were structural changes among these time-series; and January i99I was the best point at which to divide the time-series. The first part of the time frame apparently represents the downturn period, while the second part suggests a sign of rebound. We felt that it would be fruitful to repeatedly examine the relationships of the three variables under different economic circumstances.

The Johansen test was next used to detect whether the variables of this study are cointegrated over time. When variables are cointegrated, they cannot move independently of each other and their stochastic trends are linked (Enders I995, p. 355). This analysis showed that evaluation of the present situation, state of the economy and Nem York Times coverage are cointegrated with one another over time, whereas the other cointegration set (expectation, state of economy, and coverage) is not statistically significant. It makes sense that evaluation of the present situation is cointegrated with the economic index and economic coverage because they are logically associated. The public's expectation about the economy, however, is not entirely reflective of the current economic situation, which results in the insignificant output of its cointegration with the other two variables. This finding is worth noting since the vector autoregression (VAR) test is based on this foundation.

As the econometrics literature indicates, the existence of cointegration among variables only indicates a co-movement over time, which does not necessarily imply any causal or predictive relationship. In order to obtain a clearer picture of the relationships of these variables, we utilized an OLS-based, trivariate VAR model. ${ }^{3}$ VAR modeling allows researchers to detect any predictive relationship between the time-series variables over a certain time frame. Furthermore, VAR models are excellent when exogeneity of a variable in a system of equations cannot be determined with certainty by the researcher, which is the case in our setting. These models allow the simultaneous examination of the impact of multiple series on any given series (including the influence of the variable's own past). The trivariate VAR test executed in this study is capable of restricting

\footnotetext{
${ }^{3}$ Fuller (1976) showed that differencing of variables produces no gain in asymptotic efficiency in an autoregression even if it is appropriate. RATS' manual also claimed that differencing throws away information concerning the co-movement in the data while it produces no gains (Doan I992, pp. 8-I3). Similarly, scholars argued against differencing even if the variables contain a unit root; they maintained that the goal of VAR analysis is to determine the relationships among the variables, not the parameter estimates (Enders I995, p. 30г). Given these arguments against differencing, we decided not to difference our variables even though they are non-stationary.
} 
both the direct and indirect (via other variables in the system) impact of a variable on another in the system. Therefore, it allows us to test the significance of the total (direct and indirect) impact of a variable on another variable in the system. Therefore, it is a stronger test for causality than the Granger causality test.

The trivariate VAR test was executed repeatedly with the three time frames based on our preceding observations: (I) January 1987 to March 1996 (the whole period), (2) January 1987 to December 1990 (the downturn period), and (3) January I99I to March I 996 (the recovery period). Although both indices of people's perception were included in the VAR test, one should keep in mind that only the evaluation of the present situation significantly cointegrates with news coverage and the state of the economy while the expectation index does not.

Based on the results generated from the whole time frame, the economic indicator can predict people's evaluation of the present situation (at all lags) and news coverage (lags I and 2) (see Table I). Yet interestingly, the public's expectation was not influenced by either news coverage or even the economic reality. Another intriguing finding is that people's perceptions of the economy (both present and future) coincidentally affected the economic situation at lags 2, 3, and 4, which seemingly supports the Katonian hypothesis (Katona I964). As for the media's role in this model, the result shows no significant impact on either the public or the economy. Therefore, the hypotheses of media malady (on the economy) and media effect (on the public) are not supported when the whole period is examined.

The scenario of the trivariate relationship changes dramatically when the downturn period is investigated separately (see Table 2 ). People's assessment of the present economic situation was somehow overwhelmed by recession coverage, and ironically, entirely free of the influence of the state of the economy. A similar but less consistent media effect was also found in the public's expectation (significant at lags I and 4). On the other hand, media coverage during this period was not a reflection of reality, a finding that deviates from the preceding counterpart; however, the media did follow the people's expectation about the economy (expectation leads coverage at lags 2 through 4 ). Also in this downturn period, the media malady hypothesis seems partially supported by the finding that news coverage leads the economic indicator at some lags (particularly when people's assessment of the present situation is controlled). The public's perceptions were not found systematically influential on the economy (only for present situation at lags 3 and 4 ).

The first striking finding in the recovery period (January I99I-March I996) is that the influence over people's evaluation of the economic situation is entirely opposite to the downturn period-public perception can be predicted by the economic indicator but not by the news (see Table 3). Strangely enough, news 
TABLE I: Trivariate relationships computed for the whole period studied (January 1987 to March 1996 )

$F$-values

Relationship between the people's perception of the present situation, Nem York Times coverage, and state of economy:

\begin{tabular}{|c|c|c|c|c|c|c|}
\hline \multirow[b]{2}{*}{$\begin{array}{l}\text { Effects of: } \\
\text { Lag }\end{array}$} & \multicolumn{2}{|c|}{ On public perception } & \multicolumn{2}{|c|}{ On nems coverage } & \multicolumn{2}{|c|}{ On economy } \\
\hline & $\begin{array}{l}\text { Nems } \\
\text { coverage }\end{array}$ & Economy & $\begin{array}{c}\text { Public } \\
\text { perception }\end{array}$ & Economy & $\begin{array}{c}\text { Public } \\
\text { perception }\end{array}$ & $\begin{array}{c}\text { Nems } \\
\text { coverage }\end{array}$ \\
\hline I & І. 78 & 8.27 & O.OI & 7.99 & 2.52 & 2.06 \\
\hline 2 & І. 84 & 6.09 & 0.27 & $4 \cdot 5^{8}$ & $3 \cdot 57$ & 2.10 \\
\hline 3 & I.06 & 3.65 & 0.55 & 2.68 & 3.13 & г. 68 \\
\hline 4 & 0.99 & 2.65 & г. 98 & I.03 & $3 \cdot 37$ & 2.99 \\
\hline
\end{tabular}

Relationship between expectation, Nem York Times coverage, and state of economy:

\begin{tabular}{|c|c|c|c|c|c|c|}
\hline \multirow[b]{2}{*}{$\begin{array}{l}\text { Effects of: } \\
\text { Lag }\end{array}$} & \multicolumn{2}{|c|}{ On public expectation } & \multicolumn{2}{|c|}{ On nems coverage } & \multicolumn{2}{|c|}{ On economy } \\
\hline & $\begin{array}{l}\text { Nems } \\
\text { coverage }\end{array}$ & Economy & $\begin{array}{c}\text { Public } \\
\text { expectation }\end{array}$ & Economy & $\begin{array}{c}\text { Public } \\
\text { expectation }\end{array}$ & $\begin{array}{c}\text { Nems } \\
\text { coverage }\end{array}$ \\
\hline I & о. 6 & 0.86 & I. 92 & $7 \cdot 3^{I}$ & 0.06 & 0.62 \\
\hline 2 & 2.58 & $0.8 \mathrm{I}$ & 2.74 & $5.7 \mathrm{I}$ & 7.87 & 2.06 \\
\hline 3 & І. 26 & I.33 & $\mathrm{I} .7 \mathrm{I}$ & 3.47 & 6.25 & 2.IO \\
\hline 4 & I. 25 & I.02 & I.90 & I. 78 & 4.26 & 2.I 5 \\
\hline
\end{tabular}

Bold print: significant at the .05 level

coverage about recession in this period was not influenced by either economic reality or people's sentiment. Nor was the economic indicator systematically predicted by the two variables (although there are sporadic significant predictions). In addition, both the economy and news coverage appear to follow their own courses independent of other factors. According to Figure I, it is clear that the press in the first half of the recovery period still devoted substantial space to covering the recession problem.

\section{CONCLUSION AND DISCUSSION}

This study demonstrates the distinctive predictive relationships among news coverage, public perception, and economic reality across varied periods. Media coverage was found to be a good predictor of the public's assessment of the economy during the downturn period even after the state of the economy is controlled for. This finding seems to echo what Headrick and Lanoue (I99I) 
TABLE 2: Trivariate computed for the downturn period (January 1987 to December I990)

$F$-values

Relationship between the people's perception of the present situation, Nem York Times coverage, and state of economy:

\begin{tabular}{|c|c|c|c|c|c|c|}
\hline \multirow[b]{2}{*}{$\begin{array}{l}\text { Effects of: } \\
\text { Lag }\end{array}$} & \multicolumn{2}{|c|}{ On public perception } & \multicolumn{2}{|c|}{ On nems coverage } & \multicolumn{2}{|c|}{ On economy } \\
\hline & $\begin{array}{l}\text { Nems } \\
\text { coverage }\end{array}$ & Economy & $\begin{array}{c}\text { Public } \\
\text { perception }\end{array}$ & Economy & $\begin{array}{c}\text { Public } \\
\text { perception }\end{array}$ & $\begin{array}{l}\text { Nems } \\
\text { coverage }\end{array}$ \\
\hline$I$ & 7.48 & 1.03 & I. .88 & I.I9 & 0.49 & 8.56 \\
\hline 2 & 5.74 & $I .9 I$ & 3.76 & I.64 & 2.46 & 4.04 \\
\hline 3 & 5.48 & 1.53 & 1.74 & 0.35 & 4.46 & 2.99 \\
\hline 4 & $3 \cdot 77$ & 2.13 & 1.36 & 0.19 & 2.69 & 2.37 \\
\hline
\end{tabular}

Relationship between expectation, New York Times coverage, and state of economy:

\begin{tabular}{|c|c|c|c|c|c|c|}
\hline \multirow[b]{2}{*}{$\begin{array}{l}\text { Effects of: } \\
\text { Lag }\end{array}$} & \multicolumn{2}{|c|}{ On public expectation } & \multicolumn{2}{|c|}{ On nems coverage } & \multicolumn{2}{|c|}{ On economy } \\
\hline & $\begin{array}{l}\text { Nems } \\
\text { coverage }\end{array}$ & Economy & $\begin{array}{c}\text { Public } \\
\text { expectation }\end{array}$ & Economy & $\begin{array}{c}\text { Public } \\
\text { expectation }\end{array}$ & $\begin{array}{c}\text { Nems } \\
\text { coverage }\end{array}$ \\
\hline$I$ & 4.14 & 0.50 & 0.56 & 0.66 & $I .24$ & 3.08 \\
\hline 2 & 2.14 & 0.14 & 5.46 & 0.75 & 0.40 & $I .64$ \\
\hline 3 & $I .88$ & 0.43 & 3.93 & 0.93 & 0.59 & $I . I I$ \\
\hline 4 & 3.67 & $I .45$ & 3.19 & 0.73 & $0.2 I$ & I. 38 \\
\hline
\end{tabular}

Bold print: significant at the .05 level

discovered earlier-citizens pay greater attention to economic news during economic downturns. Furthermore, mass media during the slump seemed to reflect more of the public's perception about the economic situation and less of the economic reality. This phenomenon shows a strong symbiotic relationship between the mass media and the general public in an economic turmoil. Moreover, the phenomenon vividly indicates that a media effect only takes place under certain circumstances, as in this case during an economic slump.

The relationship among the three variables in the recovery period, however, turns out to be strikingly different. People's sentiments about the economy (both present and future) were not influenced by the news coverage but by the economic condition. Perhaps the public in this period could personally sense the effect of an improved economy in their daily lives and therefore felt less need to consult the media in this regard (Weaver et al. I98I). On the other hand, since more people were affected by the bad economy during the downturn period, personal recession experiences made individuals more susceptible to the 
TABLE 3 Trivariate computed for the recovery period (January I99I to March 1996)

$F$-values

Relationship between the people's perception of the present situation, Nem York Times coverage, and state of economy:

\begin{tabular}{|c|c|c|c|c|c|c|}
\hline \multirow[b]{2}{*}{$\begin{array}{l}\text { Effects of: } \\
\text { Lag }\end{array}$} & \multicolumn{2}{|c|}{ On public perception } & \multicolumn{2}{|c|}{ On nems coverage } & \multicolumn{2}{|c|}{ On economy } \\
\hline & $\begin{array}{l}\text { Nems } \\
\text { coverage }\end{array}$ & Economy & $\begin{array}{c}\text { Public } \\
\text { perception }\end{array}$ & Economy & $\begin{array}{c}\text { Public } \\
\text { perception }\end{array}$ & $\begin{array}{c}\text { Nems } \\
\text { coverage }\end{array}$ \\
\hline$I$ & 0.15 & II.II & 0.00 & $I .33$ & 0.05 & 3.84 \\
\hline 2 & 0.22 & $5 \cdot 33$ & 0.29 & 0.43 & 1.72 & $I . I O$ \\
\hline 3 & $0.2 I$ & 3.80 & 0.22 & 0.75 & 1.08 & 2.09 \\
\hline 4 & 0.57 & 2.45 & 0.92 & 0.65 & 0.65 & $3 \cdot 37$ \\
\hline
\end{tabular}

Relationship between expectation, Nem York Times coverage, and state of economy:

\begin{tabular}{|c|c|c|c|c|c|c|}
\hline \multirow[b]{2}{*}{$\begin{array}{l}\text { Effects of: } \\
\text { Lag }\end{array}$} & \multicolumn{2}{|c|}{ On public expectation } & \multicolumn{2}{|c|}{ On nems coverage } & \multicolumn{2}{|c|}{ On economy } \\
\hline & $\begin{array}{l}\text { Nems } \\
\text { coverage }\end{array}$ & Economy & $\begin{array}{c}\text { Public } \\
\text { expectation }\end{array}$ & Economy & $\begin{array}{c}\text { Public } \\
\text { expectation }\end{array}$ & $\begin{array}{c}\text { Nems } \\
\text { coverage }\end{array}$ \\
\hline$I$ & 0.33 & 2.53 & $0.0 I$ & 2.97 & I.63 & 2.86 \\
\hline 2 & 2.65 & $3.4 \mathrm{I}$ & 0.02 & $I .6 I$ & 4.62 & 0.59 \\
\hline 3 & 2.52 & $4 \cdot 39$ & 0.69 & $I .33$ & $2.6 I$ & 1.79 \\
\hline 4 & I.6I & 2.88 & 1.02 & 0.72 & $I .85$ & 2.93 \\
\hline
\end{tabular}

Bold print: significant at the .05 level

agenda-setting effect (Lasorsa and Wanta I990). Yet another explanation might be that after some months of extensive coverage about economic recession, people's attention spans simply diminished substantially, and they might well have been distracted by coverage devoted to the Gulf War. Research also shows that with the Gulf War adding to the news agenda, the seriousness of the economy was pushed aside for some months, especially on the public's minds (Iyengar and Simon 1993, Krosnick and Brannon I993). In line with this viewpoint, Parker (I995) contended that there were 'rally' effects caused by the Gulf War. Right after the war broke out, people's evaluations of Congress' performance, trust in government, personal finance, together with the economy were suddenly boosted by a wave of patriotic sentiment.

Interestingly, news coverage about economic problems dropped only briefly as the Gulf War erupted (also see Iyengar and Simon I993), rebounded quickly to reach another peak, and later appeared to evolve at its own pace- the amount of recession coverage cannot be predicted either by the economy or the public's 
sentiment in the recovery period. This intriguing phenomenon might be explained by the following two reasons: (I) the news media still indulged themselves with recession-related topics and were not sensitive enough to detect the economic rebound; (2) the topics of recession and recovery may be mingled in the news stories in such ways that this preliminary content analysis cannot distinguish.

Results based on the whole period of data show that the economy affected people's evaluation of the present situation but not their economic expectation and that news coverage overall did not influence people's sentiments when the state of the economy is controlled. In addition, news generally followed economic reality rather than public sentiments, which indicates that news media, when looked at in the long run, had done a good job of reflecting the economic reality. Also worth highlighting here is the intriguing finding that public opinion predicts economic condition, which supports the Katonian hypothesis and is in accordance with findings yielded from Fuhrer (1988) and Matsusaka and Sbornone (1992).

With the evidence derived from different periods of the economic situation, the conditioned impact of recession news on people's perception is assured. During an economic slump, the general public are more attentive to the news and, therefore, more likely to be affected by recession coverage. Yet, the public seems to have a remarkably keen sense about the improving economy, so they could be oblivious to the continuous recession coverage in the recovery period. When public opinion is examined over the entire period, however, it is still the economic reality that works as the better predictor.

Based on these findings, it is important to point out that the research findings of previous studies have failed to provide the whole scenario of these complex relationships. With regression analysis, both Haller and Norpoth (I997) and Stevenson et al. (1994) discovered that public perception about the economic situation strongly influenced media coverage, but the media, in turn, exerted an impact on public opinion. What could be missing in that cyclical model is each variable's past influence on itself, that is, the potential effect of autoregression was not taken into account. Additionally, the possible interaction between the predictors and their mutual impact on the dependent variable could not be sorted out and evaluated. Some of the inconclusive results in past studies might be also resolvable by using VAR test.

Blood and Phillips's (I995) study, which also used an advanced VAR test, appears to engender another kind of problem. Using almost identical methods, we were interested in exploring why our results differ. The major factors that differentiate their study and ours, and might result in the distinct findings, include the following: (I) The consumer sentiment index used in their study contains evaluations of both the past situation and the economic expectation; unlike our treatment, they did not distinguish them. (2) The sample period in 
their study includes the downturn as well as the recovery periods, which may result in a mix of the characteristics of the two. (3) The time frame of their sample is comparatively shorter-it could be harder for them to detect the different pattern of relationships across the two distinct periods.

This study indicates that situational or timing factors, such as economic conditions in this case, should be taken into account when researchers assess mass media effects. The finding of the different roles mass mediated information plays in varied situations echoes a series of classic studies completed by Donohue and his colleagues (e.g. I975) that identified the situations when a citizen's knowledge gap can be reduced. Additionally, this study also follows the call Zucker (1978) made for locating particular circumstances under which the public is influenced by news media. Nevertheless, relatively few studies (e.g. Neuman 1990) in the field so far have ingeniously incorporated situational or timing factors into their research models that assess media effects. These missing factors may very well enrich and expand our knowledge of how the media influence our attitudes, perceptions, and beliefs.

In addition, this study may exemplify the distinct modes of audience exposure and reception-people were noticeably more likely to be affected by certain information (bad news) under given circumstances (bad economy). Therefore, this finding may well remind us of the classic concepts of selective exposure, reception, and memory. Also relevant to the cognitive process of economic communication found in this study are attitudinal inertia (Saltiel and Woelfel I975), habituation or adaptation to repeated messages (Funkhouser I973), and replacement of new agendas (Zhu I992). With the limitation of aggregate data, unfortunately, we cannot ascertain the individual differences of media exposure and reception among the audiences. But suppose selective reception does involve in the processing of economic news-should the media be blamed for covering or highlighting negative news? Perhaps people's flawed 'reading' should be held responsible for their erroneous reactions toward economic news, too.

Time-series analysis allows researchers to go beyond the chicken-or-egg debate to more interesting questions that at times media do influence public opinion and possibly the events that become news while, at other times, journalists are the laggards, running after events and the public. News does not always follow the pattern of long-term economic cycles, rising and falling repeatedly and predictably over time, but rather deals with single issues that emerge, occupy journalists' and the public's attention, then recede. Walter Lippmann noted this early in the twentieth century when he described the press as a restless searchlight, illuminating first one event, then shifting to another. He might have added that the media seldom return once their attention has shifted. Therefore, even in events that are always news-presidential popularity or the economy, for example-circumstances vary enough that 
statistical analysis based on scientific, time-series models may be inappropriate. But a solution to this is not easy to find.

Another important finding is that the public's expectation about the economy is hard to predict and probably capricious, due to varied personal experience, community scenario, and media exposure. Given the results from VAR tests, it is clear that neither news coverage nor reality cues can forecast people's expectation levels. Even though MacKuen et al. (I992) claimed that it is the economic expectation rather than the present situation that influences presidential approval rating, it appears that there must be factors other than the media and the economic reality affecting people's sense of economic future.

Lastly, that recession news is obtrusive leads us to ask whether other kinds of information would yield a similar conditioned impact. Will unrelated foreign events be more likely to shorten the people's attention span than related, pressing stories like domestic recession? Even though studies (e.g. Watt et al. I993) showed larger agenda-setting effects of unobtrusive news, a systematic test of issue attributes with time-series methodology is still needed to provide a more comprehensive picture. Moreover, it could be fruitful if future research were to adopt a three-dimensional design that simultaneously examines information attributes, sociopolitical situation, and modes of audience reception. This study is only a modest start.

\section{REFERENCES}

Behr, R. L. and Iyengar, S. (1985): 'Television news, real-world cues, and changes in the public agenda', Public Opinion Quarterly, 49, 38-57.

Blood, D. J. and Phillips, P. C. B. (I995): 'Recession headline news, consumer sentiment, the state of the economy and presidential popularity: A time series analysis I989-I993', International Fournal of Public Opinion Research, 7, 2-22.

Breed, W. (I955): 'Newspaper opinion leaders and the process of standardization', Fournalism Quarterly, 32, 277-84.

Brosius, H.-B. and Kepplinger, H. M. (I990): 'The agenda-setting function of television news: Static and dynamic views', Communication Research, I7, I83-2 I I.

Brosius, H.-B. and Weimann, G. (1996): 'Who sets the agenda? Agenda-setting as a two-step flow', Communication Research, 23, 56I-80.

Brown, L. (I97I): Television: The Business behind the Box, New York, Harcourt Brace Jovanovich.

Crouse, T. (1972): The Boys on the Bus, New York, Random House.

Doan, T. A. (I992): RATS: User's Manual, Evanston, IL, Estima.

Donohue, G. A., Tichenor, P. J., and Olien, C. N. (I975): 'Mass media and the knowledge gap', Communication Research, 2, 3-23.

Enders, W. (1995): Applied Econometric Time Series, New York, John Wiley and Sons.

Fuller, W. A. (1976): Introduction to Statistical Time Series, New York, John Wiley \& Sons. 
Funkhouser, G. R. (1973): 'Trends in media coverage of the issues of the '6os', Fournalism Quarterly, 50, 533-38.

Fuhrer, J. C. (I988): 'On the information content of consumer survey expectations', Reviem of Economics and Statistics, 70, I40-4.

Gergen, D. (I992): 'Is the press to blame?' US Nems and World Report, January I3, p. 54.

Goidel, R. K. and Langley, R. E. (1995): 'Media coverage of the economy and aggregate economic evaluations: Uncovering evidence of indirect media effects', Political Research Quarterly, 48, 31 3-28.

Gonzenbach, W. J. (1996): The Media, The President, and Public Opinion: A Longitudinal Analysis of The Drug Issue, I984-I99I, Mahwah, NJ, Lawrence Erlbaum.

Haller, H. B. and Norpoth, H. (I997): 'Reality bites: News exposure and economic opinion', Public Opinion Quarterly, 6I, 555-75.

Headrick, B. and Lanoue, D. J. (I99I): 'Attention, asymmetry, and government popularity in Britain', Political Research Quarterly, 44, 67-86.

Iyengar, S. and Simon, A. (I993): 'News coverage of the Gulf crisis and public opinion: A study of agenda-setting, priming, and framing', Communication Research, 2o, $365-83$.

Johnston, J. (199I): Econometric Methods, New York, McGraw-Hill.

Katona, G. (I964): The Mass Consumption Society, New York, McGraw-Hill.

Krosnick, J. A. and Brannon, L. A. (1993): 'The media and the foundations of presidential support: George Bush and the Persian Gulf conflict', Journal of Social Issues, 49, I67-82.

Kurtz, H. (I990): 'Is the economy suffering from media malady?' Washington Post, October 28, p. Hi.

Lasorsa, D. L. and Wanta, W. (I990): 'Effects of personal, interpersonal and media experiences on issue saliences', Fournalism Quarterly, 67, 804-13.

Linden, F. (1982): 'The consumer as forecaster', Public Opinion Quarterly, 46, 353-6o.

McCombs, M. and Zhu, J.-H. (I995): 'Capacity, diversity, and volatility of the public agenda: Trends from I954 to I994', Public Opinion Quarterly, 59, 495-524.

MacKuen, M. B., Erikson, R. S., and Stimson, J. A. (1992): 'Peasants or bankers? The American electorate and the US economy', American Political Science Reviem, 86, 597-6II.

Matsusaka, J. G. and Sbornone, A. M. (I992): 'Consumer confidence and economic fluctuations'. Unpublished mimeograph. University of Chicago.

Mutz, D. C. (I992): 'Mass media and the depoliticization of personal experiences', American Fournal of Political Science, 36, 483-508.

Neuman, W. R. (1990): 'The threshold of public attention', Public Opinion Quarterly, 54, I59-76.

Parker, S. L. (1995): 'Toward an understanding of 'rally' effects: Public opinion in the Persian Gulf War', Public Opinion Quarterly, 59, 526-46.

Reese, S. D. and Danielian, L. H. (I989): 'Intermedia influence and the drug issue: Converging on cocaine'. In P. Shoemaker (ed.): Communication Campaigns about Drugs: Government, media, public, Hillsdale, NJ, Lawrence Erlbaum, pp. 29-46.

'Rrrrrrrrecession?' (200I): The Economist, January 4. 
Saltiel, J. and Woelfel, J. (1975): 'Inertia in cognitive processes: The role of accumulated information in attitude change', Human Communication Research, I, 333-44.

Samuelson, R. J. (1990): 'Let's blame the media', Nemsmeek, November I2, p. 60.

Stevenson, R. L., Gonzenbach, W. J., and David, P. (I994): 'Economic recession and the news', Mass Communications Reviem, 2I, 4-I9.

Stone, G. C. and McCombs, M. E. (I98I): 'Tracing the time lag in agenda-setting', Fournalism Quarterly, 58, I5 I-5.

Watt, J. H., Mazza, M., and Snyder, L. (I993): 'Agenda-setting effects of television news coverage and the effects decay curve', Communication Research, 20, 408-35.

Weaver, D. H., Graber, D. A., McCombs, M. E., and Eyal, C. (198I): Media Agenda-setting in a Presidential Election, New York, Praeger.

Willnat, L. and Zhu, J.-H. (I996): 'Newspaper coverage and public opinion in Hong Kong: A time-series analysis of media priming', Political Communication, I3, 23I-46.

Winter, J. P. and Eyal, C. H. (I98I): 'Agenda setting for the civil rights issue', Public Opinion Quarterly, 45, 376-83.

Wright, C. R. (I960): 'Functional analysis and mass communication', Public Opinion Quarterly, 24, 606-20.

Zhu, J.-H. (I992): 'Issue competition and attention distraction: A zero-sum theory of agenda-setting', Journalism Quarterly, 69, 825-39.

Zucker, H. G. (I978): 'The variable nature of news media influence'. In B. D. Ruben (ed.): Communication Yearbook 2, New Brunswick, NJ, Tranaction Books, pp. 225-40.

\section{BIOGRAPHICAL NOTES}

H. Denis Wu (Ph.D., University of North Carolina at Chapel Hill, I998) is assistant professor of mass communication at Louisiana State University, Baton Rouge, USA. His research interests include political communication and international communication.

Robert L. Stevenson is Kenan Professor of Journalism and Mass Communication at the University of North Carolina at Chapel Hill, USA.

Hsiao-Chi Chen (Ph.D., University of North Carolina at Chapel Hill, 1995) is associate professor of economics at National Taipei University, Taiwan. Her research interests include game theory, information economics, and environmental economics.

Z. Nuray Güner (PhD., University of North Carolina at Chapel Hill, I996) is assistant professor of finance at the Middle East Technical University, Turkey. Her research interests include asset pricing, market microstructure, and time-series analysis.

Address correspondence to H. Denis Wu, 22 I Journalism Bldg., Manship School of Mass Communication, Louisiana State University, Baton Rouge, LA 70803-7202, USA, Fax: + I 225578 2125, Email: hdeniswu@lsu.edu. 